\title{
Anathematized Church Fathers: a Gateway to Ecumenism?
}

\author{
SERAFIM SEPPÄLÄ
}

One of the ecumenically most problematic aspects in the history of the Orthodox Church is the anathemas of 431, 451 and especially the abrupt set of anathemas prescribed in 553, as several prominent Church fathers were condemned centuries after having passed away in peace with the Church. Most of them were authoritative or at least influential teachers for the holy fathers, and a number of their writings have been in use in the Orthodox tradition up to our times. Due to their de facto influence, they have an integrated presence and even important position in the tradition of the Church. Could this fact perhaps, with a fresh reading, have some ecumenical potential for our times, especially in relation to the Pre-Chalcedonian Churches and Roman Catholics?

Keywords: Patristic, Orthodox, anathema, authority, heretic; Origen, PseudoMacarius, Didymus, Evagrius, Diodore

After years of teaching a basic course in patristics, I have learned that the most puzzling enigma for students is the final destiny of many of the best early Christian authors. No one developed and deepened Christian thought more than Origen; none was more spiritual and charismatic than the enigmatic author of the Pseudo-Macarian homilies (likely, Simeon of Mesopotamia); none developed such a systematic and innovative theory of spiritual life as Evagrius did; none wrote more middle-of-the-road commentaries for the sacred script than the Antiochian fathers from Diodore to Theodore did. Nevertheless, they all were condemned or rejected, albeit in varying ways. Even for advanced scholars, the zealous pursuit for anathemas, especially in 553, is not easy to understand as a whole. However, the decisions have gained the authority of ecumenical councils, and there is no way for the Orthodox to neglect this fact. In the following, I present some reflections on these anathematized fathers and their anathemas, as well as some implications for the way we view the patristic tradition. This in turn may have some ecumenical relevance, especially in our times, when Orthodox thought is penetrated by anti-Catholic and anti-ecumenical attitude, more than is admitted by those Orthodox theologians who are active in

\footnotetext{
Serafim Seppälä, Professor of Systematic Theology and Patristics (Orthodox studies), University of Eastern Finland. Address: University of Eastern Finland, Philosophical faculty, PL 111,80101 Joensuu, Finland. E-mail: serafim.seppala@uef.fi.
} 
ecumenical forums. In fact, conservatism and fundamentalism seem to be on the rise inside all traditions, ${ }^{1}$ whether Orthodox, Catholic or Protestant.

Certainly, the anathemas are not a simple matter. Oddly enough, the Council of 553, in which most of the problematic condemnations took place, happens to be a most difficult case historically, both philologically and in terms of procedure. Lacking the original Greek text, it is not even completely certain what exactly was decided and why. In the standard modern edition, the anathemas against Origen are omitted as spurious interpolations, ${ }^{2}$ and it has been suggested that the fifteen anathemas were "never even discussed by the assembled bishops". ${ }^{3}$ In other words, the names seem to have been added to the canons afterwards, likely by the emperor Justinian. For the purposes of this paper, however, this problematic is secondary, given that the decisions gained universal acceptance in the Orthodox Church and became a part of its self-formation, and this is the present reality.

In the following, the most relevant anathematized (or otherwise rejected) fathers are reviewed in relation to their patristic reception, with some comments on their condemnations. Then, in the conclusion, a few potential ecumenical implications for the phenomenon are suggested. A number of more extreme anathematized heretics, who were rejected by the holy fathers and patristic authors during their lives unanimously enough, like Arius or Eunomius, do not belong to the argumentation of this paper - even though there may be no clear borderlines in differentiating such cases.

\section{The Case of Origen}

The influence of Origen (d. 254) on the most authoritative fathers of the Orthodox Church is well known, and here it suffices to outline some of the main aspects in his reception. Some were his students directly, like Gregory Thaumaturgus, ${ }^{4}$ and many others studied his writings and adopted his ways

1 For the present discussion on these developments, see: Aristotle Papanikolaou, George Demacopoulos (eds.), Tradition, Secularization, Fundamentalism, New York, Fordham University Press, forthcoming in 2019.

2 Norman Tanner (ed.), Decrees of the Ecumenical Councils, vol. I, Washington DC, Georgetown University Press 1990, p. 105-106. For more discussion, see: Francis-Xavier Murphy, Polycarp Sherwood, Constantinople II et Constantinople III, Paris, L'Orante 1974, p. 108109; Franz Diekamp, Die origenistischen Streitigkeiten im 6. Jahrhundert und das allgemeine Konzil, Münster Aschendorff 1899, p. 90.

3 The quotation is from a rhetorically rigorous essay on the subject by the most sophisticated Orthodox philosopher of our times: David Bentley Hart, "Saint Origen", in: The Dream-Child's Progress and Other Essays, Kettering, Angelico Press 2017, p. 283. For the fifteen accusations, see: Mark Edwards, "Origen of Alexandria", in: Ken Parry (ed.), The Wiley Blackwell Companion to Patristics, Oxford, Wiley-Blackwell 2015, p. 102-104.

4 For Saint Gregory's praise of Origen, see: Gr. Thaum., pan. Or., VI, 83-84, SC 148, p. 128. 
of theologizing, including Gregory the Theologian, Ambrose of Milan and Pseudo-Dionysius. Gregory of Nyssa leaned on Origen heavily; for example, in his commentary on the Song of Songs. According to the custom of that time, the influences were almost never explicitly credited, and modern scholars have a vast task in locating all the allusions.

Origen's most important influence, however, is not in details but in his overall approach to exegesis and way of discoursing. It is essential to grasp that Origen was not only the dominant biblical scholar and teacher of allegorical interpretations but he even laid the foundations for classical Orthodox Christology, although this may be difficult to see after the development of theological vocabulary and questioning during the fifth and sixth centuries. In the words of Beeley,

he articulated Christ's divinity, distinctness, and eternal relation to God the Father, as well as Christ's full humanity, to an extent that was unprecedented in its time and in a way that would later be seen to be faithful to the biblical witness and the rule of faith. In that respect Origen proved to be foundational for later thinking about Christ's divinity and humanity and the mystery of the Trinity. ${ }^{5}$

Origen was also the first theologian to state that the Trinity has eternally consisted of three hypostases. ${ }^{6}$

Overall, it is unquestionable that the influence of Origen is enormous, and not only on the level of particulars: it penetrates throughout the patristic heritage as a whole. "After Paul, there is no single Christian figure to whom the whole tradition is more indebted", David Bentley Hart estimates. ${ }^{7}$ However, it is also evident that some aspects of his reliance on Platonism proved to be problematic in the eyes of later fathers. In addition to the crucial question of pre-existence of souls, Origen did have problems in formulating the unity of Christ's human and divine aspects, ${ }^{8}$ as well as in defining the relation of the Divinity and physical bodies in general, as Beelay also notes.

The most interesting case among Origen's early readers is Basil the Great who represents a turning point in the history of theological argumentation. In defending his use of the expression "with the Holy Spirit" in the

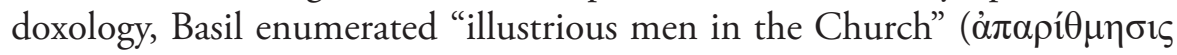

5 Christopher A. Beeley, The Unity of Christ: Continuity and Conflict in Patristic Tradition, New Haven - London, Yale University Press 2012, p. 44-45.

6 See: M. Edwards, "Origen of Alexandria”, p. 98.

7 D. B. Hart, "Saint Origen", p. 283.

8 In this respect, he was curiously akin to the later Antiochians, albeit with somewhat different vocabulary. In principle, Origen did conceive psykhē as such a unifying factor, but it did not solve all the problems.

9 C. A. Beeley, The Unity of Christ, p. 45. 


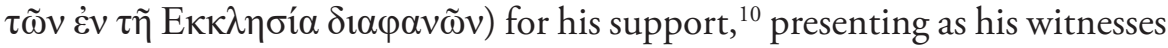
the earlier fathers Irenæus, Clement of Rome, Dionysius of Rome, Dionysius of Alexandria; then he proceeded to Origen. Basil's estimation was that "the opinions which he held concerning the Spirit were not always and everywhere sound", but "the powerful influence of tradition frequently impels men to express themselves in terms contradictory to their own opinions". The latter remark indicates that even if Origen had some personal opinions that were outside the range of the fourth century consensus, he was part of the genuine tradition of the Church and thoroughly imbued with it. This fact made him a useful authority that Basil could employ to support his own views. It did not even occur to Basil that certain eccentric notions or some mistaken opinions should make Origen an outcast.

Basil's remarks are relevant in terms of authority for several reasons. Firstly, Basil's argumentation happens to be the earliest surviving evidence for an efficient use of patristic authority in the first place. Namely, the theological argumentation was based on the sacred script alone up to the midfourth century. It was the fathers of the Nicaean Council who were first used as an authority in a similar manner, ${ }^{11}$ since they for the first time represented the voice of the whole Church, and there was none who could position himself above the authority of the whole Church. In other words, fathers were not used as an authority, and even quotations of their thoughts were surprisingly sparse. For Basil, Origen was part of this novel argumentation, ${ }^{12}$ albeit perhaps in a category of his own.

Secondly, Basil's use of Origen is balanced: it is both appreciating and critical. There is no urge for segregation, anathemas are out of question. Rather, Basil's attitude resembles Paul's "test them all; hold on to what is good". ${ }^{13}$ Basil considers Origen a strong representative of Christian tradition, with some particular ideas that were not acceptable. This is obviously a reasonable and realistic attitude to Origen's thought. Even Origen himself was aware of the fact that he was diving into profound theoretical problems without real predecessors, especially in the field of Christology, and therefore he plainly stated, "If anyone can discover something better and prove what he says by

10 Bas., Spir., XXIX, 71, SC 17, p. 502. In addition, Basil mentions Julius Africanus, "our Firmilian", and "illustrious Meletius".

11 A brief but illustrative discussion in Kenneth Parry, Depicting the Word: Byzantine iconophile thought of the eighth and ninth centuries, Leiden-New York-Köln, Brill 1996, p. 145.

12 Richard Price, "Fathers and the Church Councils", in: The Wiley Blackwell Companion to Patristics, p. 403, underlines that Basil did not refer to them as "authorities" but as "witnesses", which is technically correct. The line between authority and witness, however, is an inexact one: every authority is a witness, and the use as a witness turns authors into authorities.

131 Thess. 5.21 (NIV). 


\section{Serafim Seppälä}

clearer statements out of the Holy Scriptures, let his opinion be accepted in preference to mine!"14

In addition to the theological aspects, one should not disregard the practical state of affairs: Origen lived as a respected person in the Church, ${ }^{15}$ and he died in peace with the Church after having suffered persecution and torture for Christ and having shown extraordinary personal commitment.

The exact fate of Origen in 553 is somewhat obscure. The pope of Rome, Vigilius, did not accept any post-mortem condemnation and was excommunicated himself by the bishops of Ravenna and Milan. Consequently, Origen's works remained in use in the Western Church for centuries. In the East, he ended up offside, but how did it happen? It has been argued that the anathemas against him cannot be attributed to the actual ecumenical council, ${ }^{16}$ but in any case, they spread and influenced with conciliar authority. However that may be, Origen is mentioned also in anathemas against the Three Chapters $(\$ 11)$, which is indisputable. In the end, the great cultural tragedy was that a large number of Origen's original works disappeared due to a collapse of interest and intentional suppression.

\section{Didymus the Blind}

Another revered teacher who manifested obvious holiness and died in peace with the Church, but ended up in problems much later, was Didymus the Blind (d. c. 398). ${ }^{17}$ During his life he was a prominent opponent of Arianism, an ascetic and a saintly person, and, most of all, a famous biblical interpreter, as witnessed by his contemporary Palladius who praised him as the one who "surpassed all the ancients in knowledge". ${ }^{18}$ Being blind, his works were written down by his scribes and are flavoured with a taste of oral teaching.

Didymus's work On the Trinity (De Trinitate) is remarkable for the clarity of its Trinitarian and Christological doctrine. It is possible that he was even the first one to use the formula treis hypostaseis - mia ousia, standard-

14 Or., princ., II, 6, 7, SC 252, p. 324.

15 For instance, during his visit to Rome he was greeted with honour, as Jerome reports in De viris illustribus, 61. For discussion, see: A. Beeley, Unity of Christ, p. 7-9.

16 They are based on the nine errors of Origen as presented by the Emperor Justinian in 543. M. Edwards, "Origen of Alexandria", p. 103-104.

17 For Didymus's thought and especially biblical interpretation, see: Richard A. Layton, Didymus the Blind and his Circle in Late-antique Alexandria: Virtue and Narrative in Biblical Scholarship, Urbana-Chicago, University of Illinois Press 2004.

18 Palladius travelled to see him four times during ten years. See: Pall., h. Laus., 4, 1-2, PG 34, 1012. Besides, Palladius's text happens to be one of the most authoritative patristic readings, due to its liturgical usage: extracts from it were read in the Byzantine Matins during weekdays of the Great Lent. 
ized by Basil and others. ${ }^{19}$ In addition to his Orthodox Trinitarian dogma, Didymus also demonstrated an Orthodox Christology that corresponds to the one that emerged victorious in Chalcedon and its aftermath. The christology of Didymus benefited from the fact that in anthropological terms he was more balanced than Athanasius who, just like his Arian opponents, did not conceive a "soul" in Christ, but the inner subject was merely the divine Logos. For Didymus, the soul of Christ was an essential fact, understood to be in eternal union with the Logos. ${ }^{20}$ This exemplifies the mature character of Didymus's thinking, but it also shows that it was advantageous for him to follow Origen in this respect; for Origen, soul was the essential factor in connecting and uniting the Logos and body, and Athanasius represented a step backwards in this regard.

In short, Didymus was not only orthodox in his Christology but also somewhat ahead of his time in its formulation. Therefore, it is all the more embarrassing that his writings were condemned, albeit in a somewhat confusing way. The general council of the fifth ecumenical synod did not condemn him, but he was included in the edict ${ }^{21}$ that anathematized Evagrius, and consequently his name appeared together with other "Origenists" who were condemned in the two following synods. ${ }^{22}$ Nevertheless, Didymus was considered to belong to the Origenist group of thinkers, and for that reason his works were largely forgotten. One might call this disparagement a de facto anathema.

As for the patristic reception of Didymus, the most interesting case is Jerome who admired Didymus, called him "the seer" and co-operated with him. Jerome persuaded Didymus to compose a commentary on Zechariah and even translated his work On the Holy Spirit into Latin. ${ }^{23}$ At the outbreak of the Origenist controversy, however, Jerome changed his mind and accused Didymus of teaching apokatastasis, even though this is still not fully certain.

19 In his genuine writings, Athanasius never employed the formula of three hypostases in one Ousia. See: David M. Gwynn, "Athanasius of Alexandria", in: The Wiley Blackwell Companion, p. 114.

20 It is illustrative that in the death of Christ, according to Athanasius, it was Logos that entered Hades, but for Didymus it was His soul. Correspondingly, resurrection is unification of soul and body. Didymus is also clear in terms that the humanity of Christ was sanctified through the union with Logos, but the humanity did not lose its capability of suffering.

21 Patriarch Eutychus of Constantinople gave effect to the decree of the council.

22 For the construction(s) of Origenists, see: Elizabeth A. Clark, The Origenist Controversy: The Cultural Construction of an Early Christian Debate, Princeton, Princeton University Press 1992.

23 For discussion and references see: Frances M. Young, From Nicaea to Chalcedon: A Guide to the Literature and Its Background, London, SCM Press 2010, p. 91-101. See also: David T. Runia, Philo in Early Christian Literature: A Survey, Minneapolis, Augsburg Fortress 1994, p. 197-198. 


\section{Serafim Seppälä}

It seems that contemporary social factors - challenges by the Origenists, as well as the reactions of their opponents - contributed heavily to the way the texts of Didymus were read. In any case, Jerome in many of his biblical commentaries leaned heavily on Didymus and even gave him credit for that in the prefaces. ${ }^{24}$

The "sin" of Didymus was that he was influenced by Origen both in his approach to literal meaning and in his allegorical, spiritual interpretations, which gave him a bit of origenistic taste. However, the same could be said of Gregory of Nyssa, Gregory the Theologian and many other saints as well.

By a lucky chance, a considerable number of Didymus's writings emerged at Tura, Egypt, in 1941. The slow process of publication and research has shown that he was a faithful and even conservative thinker representing the middle line of the Church, but also that he shared the faith in the pre-existence of souls and perhaps also in apokatastasis of a kind. ${ }^{25}$ Didymus may have believed in the pre-existence of the souls, but for this anthropological flaw, the Church lost almost all of his precious writings that in all the most essential matters were more clearly Orthodox than can be expected from a fourth century author.

\section{The Messalian affair}

One of the many anti-ecumenical Orthodox authors of our times, protopresbyter George D. Metallinos, in his book The Way, presents the Orthodox faith as remedy of the soul, the other Christian traditions being unable to perform similar inner cleansing and healing. This is, according to Metallinos, because the Orthodox faith alone represents the medicine of the "proper teaching of the Bible and the dogmas (decisions) of the Ecumenical Synods". ${ }^{26}$ Thenceforth Metallinos proceeds to illuminate the faith of the synods by referring to Saint Macarius the Egyptian and his profound spiritual teaching.

So far so good. The problem, however, is that the writing in question does not originate from Egypt but from Syria, as long known by scholars, nor is it written by Macarius but most likely ${ }^{27}$ by Simeon of Mesopotamia, a Messalian character. The Messalians were condemned in the edict of Theodosius I (May 8, 381), and in the local synod of Antioch or Side in 390. Some of them caused uproar in the capital, and in spite of the considerable

\footnotetext{
24 Jerome's commentaries to Isaiah, Oseah, Daniel, Matthew, Ephesians and Galatians.

25 See: R. Layton, Didymus the Blind, p. 152. See: Didym., Trin., III, 1, PG 39, 773-776.

26 George D. Metallinos, The Way: an Introduction to the Orthodox Faith, Holy Meteora, 2013, p. 237-238.

27 The writings are attributed to Simeon in some Mss, but given the popularity of the name in Syria, it is not totally impossible that these are two different Simeons, from the same area and same period.
} 
opposition by clergy, they were admired by the monastics and some of them even entered the ranks of saints, like Alexander the Sleepless. ${ }^{28}$

The situation is not new, and the fact that it seems to repeat itself is interesting as such. In history, the same teachings have been found pure and profound when presented in the name of Saint Macarius or Saint Gregory of Nyssa, but deplorable when preserved under the name of Simon of Mesopotamia or Messalians. ${ }^{29}$ This tells much about the overall orientation of those who are keen on anathemas and canonical discipline for religious thought. Orthodoxy of contents may be difficult to estimate in synchronic terms, but the names of authors are easy labels in order to realise what is Orthodox and what is not. However, this also means that there are teachings that are fully acceptable as such, even if they originate from outside the strictest canon of saints.

Obviously, if one goes to details, the Messalian case is a most complex puzzle, ideal for academic pursuits. For one thing, it is not necessary to suppose that the Syrian author of the Pseudo-Macarian corpus belonged to an actual Messalian sect. This, however, is largely due to the fact that there was hardly any actual "sect" in the first place, but rather a loose movement and trend among Christian ascetics, something comparable to the later "Hesychasts". Moreover, it remains unclear who exactly those individuals and groups were that were labelled as "Messalians" in varying situations by their enemies, and how much did they have in common. ${ }^{30}$

In any case, the Pseudo-Macarian corpus has been highly influential in both East and West - among the most read and used spiritual texts in fact. Therefore, Meyendorff expressed the problem strikingly:

the identification of Macarius with a "Messalian" author does imply a basic judgment upon the entire tradition of Eastern Christian spirituality. For indeed, if "Macarius" is a Messalian, this entire tradition is Messalian as well. ${ }^{31}$

28 For discussion, see: Nicholas Constas, Proclus of Constantinople and the Cult of the Virgin in Late Antiquity, Leiden, Brill 2003, p. 30. See also: Columba Stewart, Working the Earth of the Heart: The Messalian Controversy in History, Texts and Language to AD 431, Oxford, Clarendon Press 1991.

29 Werner Jaeger has convincingly shown the parallelism between the "Great Letter" of Macarius and the De instituto christiano of St. Gregory of Nyssa, the first one being the original one.

30 In the words of Russell, "The consensus today is that Messalianism was not a selfconscious heresy but represents one extreme at the end of the broad spectrum of Syrian monasticism." Norman Russell, The Doctrine of Deification in the Greek Patristic Tradition, Oxford, Oxford University Press 2006, p. 241.

31 John Meyendorff, "Messalianism or anti-messalianism? A Fresh Look at the 'Macarian' Problem”, in: Kyriakon: Festschrift Johannes Quasten, vol. II, Münster, Aschendorff 1970, p. 585-590. 
Meyendorff also discussed the rather explicit parallels between the PseudoMacarian corpus and the condemnations of Messalians given by Orthodox fathers, concluding that "Such parallelisms are obviously inconceivable without Macarius having either used the Asceticon of the Messalians, or having been closely connected with circles where these expressions, considered by John of Damascus as characteristic of the sect, were widely used." 32 On the other hand, the Pseudo-Macarian corpus lacks the most striking mistaken views that the Messalians were accused of - but even this does not prove much, for the Messalians were probably condemned by using onesided exaggerations and caricatures, as often was the case. The fundamental reason may have been simply problems in personal relations and in matters related to authority, which aroused the motivation to seek for mistaken teachings.

For the time being, we may conclude that most likely the PseudoMacarian corpus represents the kind of spirituality which was condemned on the one hand and praised on the other, depending on the author's name and its reputation.

\section{Evagrius}

Evagrius was one of the most brilliant minds of the early church and the most profound ascetic author of his time. ${ }^{33}$ Ordained reader by Basil the Great and deacon by Gregory of Nyssa, Evagrius retired to the deserts of Nitria and lived ascetily under the famous desert fathers. Refusing Theophilus of Alexandria's offers of bishopric, Evagrius devoted himself fully to the ascetical life ${ }^{34}$ and literary pursuits. The result was an ingenious and unprecedented total vision of inner life set in a careful theoretical framework. ${ }^{35} \mathrm{He}$ was a praised author who made a deep influence on his readers, including many patristic saints. One result of this is that Philokalia, the "Bible of Orthodox Spirituality", still contains his famous treatise on prayer.

Some fathers, such as Jerome, started to point at certain Origenistic errors in Evagrius, but this does not seem to have taken place during his lifetime. On the contrary, his contemporary Palladius called him "blessed", "illustrious deacon", "inspired and discerning", in addition to his being an

\footnotetext{
32 Ibidem.

33 The conclusion can hardly be avoided by those who read the ascetical literature of that period. For instance, he is called "arguably the most outstanding intellect of the desert" by Susanna Elm in Virgins of God, Oxford, Clarendon 1994, p. 264.

34 Palladius described Evagrius's extreme asceticism in h. Laus., 38, 12-13, PG 34, 1099.

35 See: Julia Konstantinovsky, Evagrius Ponticus: The Making of a Gnostic, Ashgate, Ashgate Publishing 2009.
} 
opponent of Arians, the Eunomians and Apollinarians. ${ }^{36}$ It is important to note that Evagrius opposed all the three great heresies of his time.

The hunt for Origenists tracked him quite slowly, in fact. Evagrius was condemned together with Origen, first in the obscure session related to the Council of 553, the existence of which is in doubt but which proved to be effective. Whatever was the actual procedure, Evagrius was unmistakably condemned also in the Ecumenical Councils of 680 and 787, as well as in Constantinople 869. As a consequence, his works survive mostly in Syriac or Latin versions or fragments. How much he really had "Origenist heresies", is still somewhat undefined due to the loss of the Greek originals and limited amount of studies on the Syriac texts.

For the purposes of this essay, the most essential fact is that the influence of Evagrius on the Orthodox saints and patristic authors is immense and undeniable, according to scholarly research. There was, firstly, the immediate influence of his person and kerygma to figures such as Palladius, John Cassian and various desert fathers and mothers, including the author of Life of Syncletica. ${ }^{37}$ Moreover, Byzantine authors who betray his influence include names such as John (Climacus) of Sinai, Hesychius of Jerusalem, Maximos the Confessor, Niketas Stethatos, Peter of Damascus, Symeon the New Theologian, Theoleptus of Philadelphia, Gregory Palamas and other Hesychasts. In the Syriac literature, his influence is clear on writers as diverse as Philoxenus of Mabbug, Isaac of Nineveh (Isaac the Syrian) or Bar Hebraeus. ${ }^{38}$ It means that regardless of whether Evagrius was a saint or heretic (or both), his thought has penetrated Orthodox thought to the extent that it cannot even be fully separated from the latter.

\section{Diodore and Theodore}

The same problematic applies to thinkers of almost opposite poles. It was not only Origen and his like-minded who were anathematised, but also their critics and opponents from Antioch. Among the Antiochians, the most disturbing oddity is probably the fate of Diodore of Tarsus (d. 394).

36 Pall., h. Laus., 8,$11 ; 11,5 ; 12,1 ; 26,1 ; 35,3 ; 38$. 1. Palladius in fact was at times a part of his community $(35,5)$, calling Evagrius also as "my teacher" (23. 1).

37 Most of the influences are not easily discernible. A typical case is that Amma Theodora's description of akédia (depression, listlessness; PG 65, 201), which "echoes that given by her contemporary Evagrius Ponticus”, as noted by S. Elm, Virgins of God, p. 264. See: Evagr. Pont., cap. pract., SC 171, p. 512 and p. 520.

38 For details, see: Blossom Stefaniw, "Evagrius and Authority" in: Robin Darling Young, Joel Kalvesmaki (eds.), Evagrius and His Legacy, Notre Dame, Notre Dame University Press 2016, p. 96-127; C. Stewart, "Evagrius beyond Byzantium: The Latin and Syriac Receptions", in: Ibidem, p. 206-233; Gregory Collins, "The Evagrian heritage in Late Byzantine Monasticism", in: Ibidem, p. 317-330. 
Firstly, there is no doubt that he spent his life defending the Nicaean orthodoxy and opposing Julian the Apostate and Arianism; and consequently he was ordained bishop at the death of Arian emperor, Valens, in 378. In his asketerion, Diodore was the teacher of John Chrysostom and a trustworthy teacher of the Scriptures until the end of his life in 394.

Diodore was remembered as a saintly character. The most famous documentation of this is the fact that John Chrysostom held an eulogy in his honour in 392, in his very presence. After having been praised by his teacher, Chrysostom turned the praise back and called Diodore his "teacher" and "father", comparing him with John the Baptist. ${ }^{39}$

After his death, Diodore was attacked by Cyril of Alexandria who, in addition to Nestorius, also pursued his teachers, especially Theodore of Mopsuestia (a friend of John Chrysostom), but also Diodore who was the teacher of both Theodore and Chrysostom. As a result of Diodore's somewhat inept and stiff way of underlining the difference between human and divine actions (beings) in Christ ${ }^{40}$, he was accused of dividing Christ into two, and in 499, the local synod of Constantinople deemed his theology as Nestorian. Oddly, in the end Diodore was and was not condemned. $\mathrm{He}$ is not explicitly mentioned in the anathemas against the Three Chapters, although he was largely understood to be in the same group with Nestorius and Theodore. Cyril declared him heretic, but the actual texts he was blamed for, were by Theodore. The result was a curious implicit condemnation, which made him a de facto heretic, though perhaps not de jure. Regrettably, this was enough to result in the loss of his works, even though some of them were still circulating at the time of Photios. ${ }^{41}$

Moreover, it seems rather obvious that the treatment of Theodore of Mopsuestia himself was also far from just in 553. Text of the Council makes megalomaniac rhetoric against him but fails to present much concrete proof of his heresy, with the exception of deliberate misunderstandings and exag-

39 John Chrysostom, Diod., $P G 52,761-766$. The text in the $P G$ edition is a bit confused on the last point.

40 For a sample of Diodore's Christological quotes and discussion, see: D.S. Wallace-Hadrill, Christian Antioch: a study of early Christian thought in the East, Cambridge University Press, 1982, p. 119-122.

${ }^{41}$ Commentary on Psalms 1-51 resurfaced in the twentieth century, translation by Robert C. Hill, in: Writings from the Greco-Roman World 9, Society of Biblical Literature 2005. However, it would not be utterly surprising if some of Diodore's (or Theodore's) works had survived in the name of John Chrysostom. Or, Chrysostom may have derived some of his teaching directly from Diodore's works. Marie-Émile Boismard, Arnaud Lamouille, Un évangile pré-johannique I: Jean 1,1-2,12, Études bibliques 17-18, Paris 1993, have suggested that in Chrysostom's famous Homilies on John the theological first parts of the homilies are based on Diodore, and the following ethical parts are Chrysostom's own contribution. 
gerations such as his supposed doctrine of "two Christs". This question on the inter-relations between prosopon, fysis and hypostasis is too complicated to be pursued here in depth, but it is worth noting that Theodore, like Nestorius, was in many ways closer to Chalcedon than Cyril, yet his theological approach was somewhat clumsy indeed. Theodore did have serious problems in keeping the divine and human aspects of Christ in balance and as one subject. This was essentially a refined conceptual problem of maintaining both sides of the paradox together with the help of abstract vocabulary, but his problematic expressions were treated with the same vigour as frankly unorthodox Arian Christology. Theodore's influence was limited mostly to the Church of the East, and therefore he is of less interest here.

In any case, the whole pursuit of attacking the deceased members of the Church was thoroughly problematic, given that they could no longer defend themselves. The synod itself understood that to condemn Christians who had died centuries ago in peace with the Church was uncomfortable, and therefore it made a long apology for this questionable practice. Good arguments lacking, the synod resorted to Augustine - one of the few times that the Eastern Church tried to argue on the basis of a Western author. ${ }^{42}$

\section{Is there a spiritual attitude to anathemas? A view from the desert}

What, then, should one think of these fathers, and how? The fates, thoughts and textual traditions dealing with them is a most complicated field, and there seems to be, in addition to the complex dogmatic, philological and philosophical aspects, multi-layered ethical and spiritual issues involved. Given that the approach to details is largely determined by attitudes, it is both academically and spiritually important to consider this question carefully.

In Orthodox spirituality, humility and disdain for condemning others are the most fundamental virtues and ideals. Evidently, it is difficult to synchronize this with the urge for condemning others in doctrinal matters. In some sayings of the desert fathers, the paradox was solved simply by hinting that doctrinal matters are to be excluded from the virtue of not judging. ${ }^{43}$

\footnotetext{
42 Arguments included also a few NT references (Jn. 3.18; Gal. 1.8-9; Tit. 3.10-11), in addition to references to Cyril and certain African bishops and Roman popes, Sentencia Synodica 12-17. For discussion, see: Aloys Grillmeier, Christ in Christian tradition, vol. 2: From the Council of Chalcedon to Gregory the Great. Part Two: the Church of Constantinople in the Sixth Century, London, Mowbray 1995, p. 445.

43 The most famous example is Abba Agathon's Apophthegmata 5: "[...] 'Aren't you Agathon the heretic?' But at that he replied 'I am not a heretic.' So they asked him, 'Tell us why you accepted everything we cast you, but repudiated this last insult.' He replied: 'The first accusations I take to myself, for that is good for my soul. But heresy is separation from God. Now I have no wish to be separated from God." Even in this case, however, the focus is in one's own self, not in condemning others.
} 
This is of course the simplest solution, but one may ask whether it is completely honest, and how far it can be applied in relation to others.

This very problem was discussed in the letters of Barsanuphius and John, the famous elders of Gaza in the sixth century. When asked by a Christian whether he should "anathematize Nestorius and the heretics with him", the elders answered by firstly stating that the fact that they are under anathema is clear - in other words, there is no more use of arguing about that. "But", they continued, one "should never hasten to anathematize anyone at all": it would be better to focus on his own shortcomings instead. And on the other hand, it is equally important not to judge those who do anathematize someone. ${ }^{44}$ In other words, it is spiritually beneficial to distance oneself from such procedures and the attitudes connected with them.

The elders then faced a subsequent question: if one is considered heretic himself because of taking distance to anathematizing, what to do? The elders recommended confirming that "those people were worthy of their anathema", but to simultaneously state that "I am more sinful than every other person, and I fear that, in judging anyone else, I may actually condemn myself". Barsanuphius and John argued that even to anathematise Satan himself does not help if one does the works of Satan; and whoever does not love the Lord and do his works, is already under anathema, according to the apostle, ${ }^{45}$ and therefore caution is needed. The argument gently hints that there is perhaps no essential difference between me and them.

If one is still blamed for not anathematizing, however, the final advice of the elders was to declare ignorance of the beliefs of the anathematised ones and to state simply, "Beyond the faith of the holy 318 fathers, I know no other faith; and one who believes contrary to this casts oneself under anathema." 46 The answer is remarkable for showing a plain attitude that the faith of Nicaea is unquestionable and solid, but the anathemas since 431 are something else: more complicated, more nuanced, more varied, more developed, and conducted of more complex motives. ${ }^{47}$ Moreover, the anathemas from 431 to 553 do not merely demarcate certain heretics outside the Church: they also serve to break the tradition of the Church itself, for those excluded have their influence present inside the holy tradition. Furthermore, the differences between the Orthodox fathers and the anathematised ones are in many cases extremely vague. Since many expressions corresponding to the condemned ones appear also in the writings of holy fathers, the differ-

\footnotetext{
44 Bars., resp., 699.

45 Idem, resp., 700, see: 1 Cor. 16.22 .

46 Idem, resp., 701.

47 Perhaps the elders had also witnessed how saintly Christians those labelled as "Nestorians" or "Monophysites" could be.
} 
ences to Orthodoxy must be considered more or less relative. This also shows in the fact that the condemned figures delivered the essentials of apostolic tradition $^{48}$ into the non-Chalcedonian Churches.

In more synchronic terms, the caution is needed exactly because of the synchronically unclear boundaries between patristic Orthodoxy and noncanonical heterodoxy. Anathemas of 553 made this worse in the sense that they removed from the Church an incredible amount of literature that had been considered Orthodox, or at least not heterodox, for centuries. Dozens and dozens of saints had read hundreds of works without knowing that the status of these works might change after centuries.

\section{Conclusions and ecumenical implications}

What does this all mean? And what could it mean for today? The more one gets acquainted with the thought of the anathematised fathers in detail, the more oblique the cases appear. Even without going into details, however, one may ask: if writers such as Origen and Evagrius were not real heretics, why then were they condemned? If they were heretics, how come the Orthodox tradition is full of their thought? And how come their heterodoxy was not noticed during their lives? On the contrary, figures like Origen, Didymus the Blind, Diodore and Evagrius were highly praised by the contemporary patristic authors.

The failure of 553 and its follow-ups in evaluating the authors of the early Church was first of all a failure in diachronic understanding. Writers were evaluated synchronically, by sifting and sieving for detached mistakes as if they were writing in the sixth century and answering to post-Chalcedonian questioning. It seems that those who set the final judgements failed to see the fathers in their own context, and consequently, even those who originally were even ahead of their time (Origen, Didymus) were not appreciated.

Perhaps even more confusingly, Origen, Evagrius and Didymus were not rejected because of their lives, or careers as teachers, not even so much because of their actual writings, but because of the "Origenistic movement" centuries after them. Problems of authority contributed to the schism, and even more so in the case of Messalians. The obvious problem is that the discussion was going on with constantly progressing questioning, and it was no longer possible for the deceased fathers to follow the discussion or to defend themselves. Almost certainly, they would not have signed all the claims connected with Origenism of the sixth century, not to mention the absurdities for which Theodore was blamed. This makes the whole procedure somewhat bizarre.

48 It is to be recalled that the Christology of figures such as Athanasius, Cyril of Alexandria and Gregory the Theologian is normative in the Oriental Churches. 
Furthermore, Origen, especially in his early career, had a tendency (that we might call "academic") to try different viewpoints, without necessarily signing them all or considering them the ultimate truth. Besides, the tentative speculations dealing with subjects that have no biblical answers occur mainly in his letters to his inner circle, and the function of these should be differentiated from his public teaching in the Church. Relativeness in all of its forms, however, was a completely alien concept to the theological procedure in 553. Moreover, the fifth-sixth century Orthodox fathers evidently were unable to grasp the change and development within the tradition: most of them probably felt like defending Nicaea and certainly not making advances or developments. ${ }^{49}$

It should be obvious that serious mistakes took place, but it is also important to realise the nature of these inaccuracies. Of course, it is possible to argue simply that the Church has full right to self-definition, and in that sense the Church is even unable to make mistakes: whatever the ecumenical synod decides and states, is the voice of the Church that defines her identity and boundaries, and whomever the synod anathematizes, is outside by definition, regardless of arguments or reasons, or lack of them. From this perspective, the mistakes are mistakes in the intellectual and ethical senses only, in that they fail to do justice or to appreciate the targets objectively from all sides. For the same reason, however, to estimate the mistakenness of decisions in 553 is an academic exercise only. What is more relevant in practice is the actual result and outcome.

If the Orthodox take a tough stand, the anathematized fathers like Origen are simply to be rejected altogether, and that is the end of the discussion. At the same time, however, it is also true that the thought of Origen, his methods of biblical exegesis and its contents, his textual criticism, and even his dogmatic lines do remain an integral part of the purest Orthodox tradition and patristic thinking. This applies also to the other anathematised fathers from Simeon of Mesopotamia to Evagrius and the Antiochians, albeit perhaps in varying degrees, even if each one presents a very complicated case when it comes to the actual philological details.

The result is that there are fathers who are technically outside the Church, yet with profound and wide influence inside the uncontaminated tradition. Among all the churches, the Orthodox have the most rigorously guarded holy tradition, but paradoxically, it is exactly this rigorous guarding, which has resulted in a certain anomaly. By anathematising fathers like Origen, Evagrius and Didymus, and rejecting ones like Simeon of Mesopotamia and Diodore of Tarsus, the church has de facto rejected parts of itself. Or,

49 For discussion, see: R. Price, "Fathers and the Church Councils", p. 409-410. 
looking from the opposite perspective, the Orthodox Church has admitted certain suspicious and even banned entities into her own flock. If Evagrius and Simeon of Mesopotamia were heretics, why is our spirituality so deeply Evagrian and Messalian? In fact, it is exactly a combination and synthesis of these two.

The view that there is the pure Orthodox doctrine inside and the opposing heresies outside is an abstraction that does not correspond to reality when viewed in detail. The anathemas in question break, or at least relativize, the possibility of seeing the patristic tradition in simple terms of (pure) inside and (impure) outside. In that sense, the borderlines of Orthodoxy and non-Orthodoxy do not appear completely logical neither in diachronic nor in synchronic terms. Since the orthodox Church has in her tradition a plentiful amount of patristic teaching from teachers that do not fall within the scope of seven ecumenical councils, but are explicitly (or de facto) condemned, there is no way to define the borders of Orthodoxy and non-orthodoxy in a precise or even fixed way. The illusion of inside and outside is created with the help of labels such as personal names or detached doctrinal terms that can be used as slogans and banners.

The long rhetorical apologies given in 553 for the possibility of anathematizing deceased fathers failed to take into account that the fathers were not detached individuals but they had already thoroughly integrated into the tradition. The condemnation of characters that are more or less an integral part of the tradition introduces to the ecclesiology an element of relativeness and even certain insecurity. How can I know that the bishop or monastic authority I am listening to today is not anathematised after 300 years? The question is perhaps an absurdity in modern times, but it is an absurdity that never occurred to the Christians of third and fourth centuries either.

Moreover, there were also what might be called philosophical failures in evaluating the correctness of patristic authors, especially after Chalcedon. Firstly, the philosophy of language seems to have been much too positive; the naïve faith in the possibility of exact expression was strong - even though the subject was a mysterious paradox. Therefore, the discussion remained artificial, even when it became more and more exact on the surface. Secondly, the quest for more and more exact expression for the paradox of Christ, even if it was a legitimate pursuit in itself, does not imply that the previous less sophisticated usages should be considered incorrect and evil. If some Antiochian fathers used terms ambiguously or clumsily, why not admit that their expression was $10 \%$ or $20 \%$ short of perfection? Why demonize them as if they were dedicated enemies of the truth? One might in fact detect a lack of perfection (if defined as doctrinal exactness) from practically all the fathers, when it comes to the exact expression of paradox. Why not anathematize 
St. Cyril for his promotion of the one-nature Christ, or his occasional use of physis and hypostasis as synonyms, resulting in "half-monophysitism"? Why not anathematize Athanasius and others whose Christ had no human soul? Moreover, Athanasius divided the divine Logos and human sarx very much in the same way as Theodore and Antiochians did using different terms. ${ }^{50}$ These questions are, of course, merely rhetorical. Yet Theodore's anathema was not much fairer. In this respect, the paradigm was a completely black-orwhite one, and a modest inadequacy in clarity was treated in the same way as the fundamental error of Arianism.

Now one may present a counter objection: certain fathers have indeed been rejected because of certain mistakes they made, but they were not mistaken in all respects, and thus their Orthodox thoughts may well dwell and circulate inside the holy tradition, so why the fuss?

The objection is understandable, and it is actually the final point of this paper. Namely, if there are fathers and authors who are not absolutely Orthodox in some points, but fully Orthodox in others, why not read and use them? If an Orthodox cleric or theologian wants to employ the idealism and asceticism of Francis of Assisi, the spiritual fervour and psychological depths of Catholic mystics, or perhaps the profound vision of Nikos Kazantzakis, why should there be any fuss? (All examples have been fiercely attacked by certain Greek Orthodox authors of modern times.) This is much more so in the case of authors who explicitly build on the same patristic tradition as the Byzantine fathers.

The complicated nature of anathemas offers a kind of precedent for an option to reduce suspicions against the later non-Chalcedonian patristic authors or Roman Catholic Saints. It is more difficult, however, to estimate whether this principle could be applied among the authors of various Protestant groups, who by definition are rather far from the idea of patristic authority.

An interesting precedent in this respect is Isaac of Nineveh who ended up in the Orthodox canon inspite of his East Syrian ("Nestorian") background. It is telling that in the influential Greek translation of Isaac, the numerous references to Theodore of Mopsuestia, Diodore or Evagrius - an unholy and unlikely alliance! - were replaced with names like Cyril of Alex-

\footnotetext{
50 In some places, Athanasius even seems to indicate that the divine aspect (Logos) of Christ

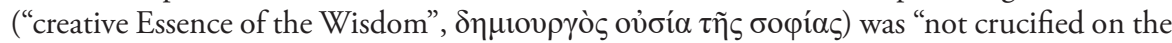
tree but only the body". See: Ath., ep. Epict., 2, PG 26, 1053A. This is the very problem for which the Antiochians were blamed, and which Gregory the Theologian opposed with his solemn vision of God on the cross. However, Athanasius later explained that in the body that was nailed there was the Logos. Ath., ep. Epict., 5 and 10. Theodore was condemned for such discrepancies, or shortness in clarity.
} 
andria, but the quotations themselves were left untouched. The result was that their ideas bothered no-one, which is a brilliant example of the fact that for purists the canonical labels matter more than contents. Moreover, Isaac has been among the most highly ranked authors for Hesychasts and modern saints, such as Paisius Velichkovsky, Elder Paisios of Mount Athos, or John of Valamo ${ }^{51}$. Thanks to the huge influence of Isaac, the whole genre of East Syrian mystical theology is of immediate interest for the Orthodox.

The easiest case in this respect, however, should be those non-Chalcedonian fathers of the Oriental Churches who were accused of being too Byzantine-minded by members of their own Church. In the Armenian Church, the most interesting cases in this respect are Xosrow Anjewaci and his son Gregory of Narek, the most beloved author in the Armenian tradition. ${ }^{52}$ If they were accused of theological Byzantine-mindedness by some of their fellow-Armenians, it would be only polite to show some appreciation and certain "ecumenical" approval for them. If this sounds unrealistic or artificial, one may note that the Roman Catholic Church did nominate Gregory of Narek among the "doctors of the Church" in an unprecedented move in 2015 - a non-Catholic doctor for the Catholics! ${ }^{53}$

However that may be, the Orthodox should at least know their own tradition well enough to understand that the limits and borders of the tradition are not clear-cut. In short, as far as the Orthodox patristic tradition represents the true doctrine, it does not represent it in the absolute sense, but in a relative one. This is actually obvious for the simple reason that human language is a relative phenomenon in any case, especially so in the case of mysteries. Perhaps the ultimate example of this relativity is the fact, preserved in Syriac, that Nestorius himself was very pleased with the Chalcedon definition, which summarised his views better than he himself had been able to do in the 430's. ${ }^{54}$ From the other perspective, this means that the Ortho-

51 John of Valamo is a new saint (ethnically Russian) of the Finnish Orthodox Church who is to be canonised in June 2019. For him, Isaac the Syrian represented the most profound teaching of the Church, and a bishop who criticised Isaac just had "too short a rope" to draw refreshing water from Isaac's depths! Skeemaigumeni Johannes, Kirjeitä Innalle, Valamon luostari, 2014, p. 14.

52 See: Xosrow Anjewac'i, Commentary on the Divine Liturgy, translated with an introduction by S. Peter Cowe, New York, St. Vartan Press 1991, p. 9.

53 Nevertheless, Gregory of Narek and many other "Monophysite Saints" had de facto entered the ranks of Catholic saints as if through the back door, at the emergence of Uniate Churches who brought their saints into Catholic jurisdiction.

54 "When I was silent, and the authority to say them [had been] taken away from me, and I was not believed, God raised up those [men], who were believed when they said these [same] things as I, which were the truth, without there being any suspicion therein of their having said these things out of friendship or out of love for me. And God brought these things 
dox tradition is already "ecumenical" in the modern sense, since it contains deeply-penetrating elements of others, such as Origenists and Messalians, as well as East Syrians and "Monophysites"; and on the other hand, the latter two share the early patristic tradition with the Orthodox in any case.

Correspondingly, the authority and tradition of the non-anathematized holy fathers could be used in more penetrating ways in search of common authoritative ground with those Churches that have faith in the authority of the patristic authors. Too often, however, Orthodox theologians have utilised fathers such as Photios or Cappadocians in order to choose from them remarks that serve anti-Catholic aims, leaving their other expressions aside.

It is probably true that the Orthodox Church is unable to make any ecumenical (in both senses of the word) decisions and steps forward for centuries to come, but at least the theologians and authorities of the Church should be able to consider the injustices done in 553 and their possible implications from varying perspectives. Moreover, one could also wonder: if the Church can condemn teachers 300 years after their death because their teaching does not fulfil all the requirements of that later period, why should the Church be unable to review the decisions and show mercy afterwards? In an objective reading, too many of their mistakes appear to be either marginal errors, speculative opinions, or due to anachronistic reading or philosophically inadequate premises - even if they can still be considered mistakes, or perhaps rather, failures. In any case, it should be obvious that third-fourth century responses should not be judged on the basis on fifth-sixth century questions. If, say, Apostle Paul was read with the post-Chalcedonian questioning, ${ }^{55}$ there would be no hope for him to avoid anathema.

It is also true that there is a fundamental difference in that the fathers discussed in this paper all came from inside the Church, as the modern Christian authors may be of outer origin. But it ought to be better to be accepted inside from outside than be cast out from inside.

about, not on my account." Nestorius, Bazaar of Heracleides, 2, 2, translated and edited by G. R. Driver, Leonard Hodgson, Oxford, Clarendon 1925, p. 374. For discussion, see: D. S. Wallace-Hadrill, Christian Antioch, p. 131.

55 This is reflected in one of the later accusations against Origen. He was accused for forbidding prayer to the Son and preferring prayer to the Father to the Son instead; the Anglican divine George Bull noted that Origen simply preached what the New Testament prescribes. See the discussion in M. Edwards, "Origen of Alexandria", p. 106. 